\title{
Military Ethics of Fighting Terror: Principles
}

\author{
Asa Kasher • Amos Yadlin
}

Published online: 27 July 2006

C) Springer Science + Business Media B.V. 2006

\begin{abstract}
The purpose of the present document is to briefly present principles that constitute a new doctrine within the sphere of Military Ethics: The Just War Doctrine of Fighting Terror.

The doctrine has been developed by a team we have headed at the Israel Defense Force (IDF) College of National Defense. However, the work has been done on the general levels of moral, ethical and legal considerations that should guide a democratic state when it faces terrorist activities committed against its citizens. Accordingly, the proposed principles are meant to be justified and practically applicable under any parallel circumstances. Moreover, those principles are intended to be universal in the sense that the justification of none of them rests on any particular stance with respect to the desired solution of the conflict under consideration.
\end{abstract}

Keywords Military ethics $\cdot$ Fighting terror $\cdot$ Just War Doctrine $\cdot$ Self-defense $\cdot$ Military necessity $\cdot$ Principles $\cdot$ Distinction $\cdot$ Proportionality $\cdot$ Israel

The present new feature of Philosophia brings to the attention of the readers a document that seems to be of philosophical interest. Readers are encouraged to submit their comments on the document for publication in Philosophia.

The document presented in the sequel is in Military Ethics. A fully fledged philosophical presentation and defense of the principles included in the document appears in a paper entitled

"Military Ethics of Fighting Terror: An Israeli Perspective," written by the same authors and published in the Journal of Military Ethics 4:1 (2005) 3-32.

Editor, Philosophia

\footnotetext{
A. Kasher $(\bowtie) \cdot$ A. Yadlin

Laura Schwarz-Kipp Chair of Professional Ethics and Philosophy of Practice,

Tel Aviv University, Tel Aviv, Israel

e-mail: kasher@post.tau.ac.il
}

A. Kasher $\cdot$ A. Yadlin

IDF College of National Defense, Tel Aviv, Israel 
At our starting point we have to adopt or suggest a working definition of 'terror activity.' We are aware of numerous definitions of 'terror' that have appeared in the political arena and the professional literature of different disciplines. ${ }^{1}$ We have adopted some of the major ubiquitous ingredients of those definitions, but have phrased our own definition for reasons that will become clear in a moment.

We define an 'act of terror' as:

(T) an act, carried out by individuals or organizations, not on the behalf of any state, for the purpose of killing or otherwise injuring persons, insofar as they are members of a particular population, in order to instill fear among the members of that population ('terrorize' them), so as to cause them to change the nature of the related regime or of the related government or of policies implemented by related institutions, whether for political or ideological (including religious) reasons.

Two ingredients of definition $(\mathrm{T})$ require clarification. The first has to do with the agents of acts of terror. Under consideration in the present work are acts (and activities, which are series of acts) that are carried out by individuals or organizations, but not on the behalf of a state. We do not deny that a state can act for the purpose of killing persons in order to terrorize a population with the goal of achieving some political or ideological goal. However, when such acts are performed on the behalf of a state, or by some of its overt or covert agencies or proxies, we apply to the ensuing conflict moral, ethical and legal principles that are commonly held to pertain to ordinary international conflicts between states or similar political entities. ${ }^{2}$ Since the nature of the situation in which a state faces acts of terror committed by individuals and organizations is rather different from that of a state facing acts of terror committed by another state, we take it that those cases should be discussed separately. Strictly speaking then, our definition (T) of 'act of terror' is a working definition rather than a complete depiction of a certain type of act.

The second ingredient of definition $(\mathrm{T})$ requiring clarification has to do with the fact that the targets of acts of terror are persons in general, not necessarily noncombatants. ${ }^{3}$ Put differently, we define 'act of terror' in a way that makes it possible for the victims of such an act to be combatants, even exclusively so.

We do not deny the fact that occasionally acts of guerilla warfare are similar to acts of terror, in some respects. Acts of both kinds can be conducted by persons who live in seemingly ordinary residential areas and use them for planning their acts and hiding from their enemies. However, guerrilla warfare differs from terror activity in that it is conducted primarily for the purpose of disrupting military activity through the use of military or quasimilitary means and methods. Guerilla warfare is intended against military targets or infrastructure targets that support military forces within a territory those forces occupy. Guerilla acts are very similar to military acts, whereas acts of terror are very different from them. Hence, principles related to fighting terror and principles related to anti-guerilla warfare should be treated separately, forming separate parts of Military Ethics.

\footnotetext{
${ }^{1}$ For a philosophical discussion of several definitions, see Corlett (2003: 116-121). A 1988 guide, Schmid, Jongman, et al. (1988) enumerates 109 different definitions. The present figure would be above 150 .

${ }^{2}$ In such a context, a state that killed numerous citizens of another state in order to terrorize its citizenry would be guilty of what is commonly regarded as a war crime. Interestingly and regrettably, there is no international treaty against terror that would define terror crimes of individuals, organizations and states.

${ }^{3}$ The UK Terrorism Act 2000 too define acts of 'terror' without confining targets to noncombatants only. 
Definition (T) is a working definition of an 'act of terror.' A naturally related working definition would be that of an 'activity of terror,' which involves individuals or organizations that regularly try to carry out acts of terror or seriously threaten to do so.

The following principles constitute our proposed doctrine for military ethics (Just War) of fighting terror. The proposed principles are meant to serve in considerations of acts and activities within the framework of fighting terror. Such considerations often appear during explicit deliberation, but they can play a role when acts or activities are pondered. They can take place on each level and at each stage of a fight against terror. Thus, they can take place on strategic as well as operational or tactical levels. Similarly, they can take place at the planning stage of a mission and while it is being carried out, as well as during professional debriefing or public presentation after a mission has been accomplished.

\section{Principles of Fighting Terror, Part I: State Level}

The first two principles are meant to apply on the level of the state, when it faces terror activity. They serve as general starting points of considerations related to the moral and ethical dimensions of the fight of a democratic state against acts and activities of terror.

Principle A.1

\section{The Principle of Self-Defense Duty}

(1) It is the prime duty of a democratic state to effectively defend its citizens against any danger posed to their lives and well being by acts or activities of terror, both in the short run and in the long run.

(2) In doing so, the state discharges its obligation to protect the human dignity of the citizen, both as person and as citizen.

(3) Moreover, being a democratic state, it must fulfill its obligation while properly respecting the human dignity of each person, as a person.

\section{Principle A.2}

\section{The Principle of Mission}

The state will discharge its obligation to effectively defend its citizens against acts and activities of terror by means of its various forces and services, each in accordance with its mission, capabilities, and methods, and each observing its distinctive ethical principles.

\section{Principles of Fighting Terror, Part II: Military Preventive Activity}

The fight of a state against terror takes place in two separate, though related, battlegrounds. Since a terror act or activity is carried out 'for the purpose of killing or otherwise injuring persons, insofar as they are members of a particular population, in order to instill fear among the members of that population,' one battlefront is drawn in an attempt to defend the members of the target population from being killed or otherwise injured. Since every once in a while people do get killed by terrorists, the threat of being killed by terrorist and 
therefore the danger of fear being instilled among the members of the target population do not disappear. As a result, a second battlefront is drawn in an attempt to defend the target population from being terrorized. Principles related to the former battlefront are discussed in the present part of the paper, while those pertaining to the latter one will be discussed in next part (III).

\section{Principle B.1}

\section{The Principle of Military Necessity}

Military acts and activities against terror are right only if they are carried out under the following conditions:

(1) Purpose Condition:

The act or activity is taken in fulfillment of the basic duty of the state to defend its citizens from terror acts and activities.

(2) Relative Effectiveness Condition:

Any alternative act or activity (including refraining from any act or activity, respectively) would expose the lives or well being of the citizens of the state, including its combatants, to greater danger.

(3) Minimizing Collateral Damage Condition:

The act or activity is carried out in a manner that strictly protects human life and dignity by minimizing all collateral damage to individuals not directly involved in acts or activities of terror.

(4) Proportionality Condition:

The act or activity is carried out in a manner that takes into account the relationship between its contribution to the defense of citizens from dangers of terror and the collateral damage it causes.

(5) Fairness (or universalizability) condition:

The act or activity is of universal applicability: Its justification would justify carrying out parallel acts or parallel activities in all parallel situations.

\section{Principle B.2}

\section{The Principle of Distinction}

\section{(a) Different types of State Duties}

Military acts and activities, carried out in discharging the duty of the state to defend its citizens against terror acts or activities while at the same time protecting human dignity, should take into account, to the greatest possible extent, the distinctions between different types of duties of the state. Here are duties of the state with respect to different types of persons who are neither its citizens nor its residents:

(a.1) The duties of the state toward persons who are not involved in acts or activities of terror and are under the effective control of the state;

(a.2) The duties of the state toward persons who are not involved in acts or activities of terror and are not under the effective control of the state;

(a.3) The duties of the state toward persons who are indirectly involved in acts or activities of terror; 
(a.4) The duties of the state toward persons who are directly involved in acts or activities of terror.

\section{(b) Different Types of Direct Involvement in Terror}

Military acts and activities, carried out in discharging the duty of the state to defend its citizens against terror acts or activities, while at the same time protecting human dignity, should take into account, to the greatest possible extent, the distinctions between different types of direct involvement in terror. Here is a scale of direct involvement in terror acts or activities, in the order of relative imminence of the danger posed by involvement:

(b.1) Persons posing an immediate danger (e.g., a bearer of an explosive belt);

(b.2) Persons providing immediate support to persons posing an immediate danger (e.g., a driver, a guide);

(b.3) Persons dispatching other persons to pose an immediate danger;

(b.4) Persons preparing devices for acts or activities of terror (e.g., an 'engineer,' producing explosive belts, or the director of a 'laboratory' of such production);

(b.5) Persons providing essential ingredients of devices of terror (e.g., a 'pharmacist,' deliberately supplying major ingredients of explosives, or a person who lends crucial funds);

(b.6) Persons planning an act or activity of terror, whether its operational idea or its practical details;

(b.7) Persons recruiting certain other persons to carry out acts or activities of terror;

(b.8) Persons making operational decisions to carry out a planned act or activity of terror;

(b.9) Persons making general operational decisions related to acts or activities of terror (e.g., a decision to adopt a policy of making attempts to carry out acts or activities of terror, or granting permission for certain women to participate in an activity of terror and bear explosive belts).

Any person who is involved in acts or activities of terror of types (b.1)-(b.9) is regarded as being directly involved in terror.

Ascription of any type of direct involvement in terror to a certain person ought to be made only on grounds of reliable, updated and convincing evidence. Such evidence may be probable rather than certain.

Any person who is involved in acts or activities of terror in some other way is regarded as being indirectly involved in terror. Examples of such indirect involvement in terror would be:

(b.10) Developing and operating funding channels that are not crucial to acts or activities of terror;

(b.11) Preaching in a mosque in general praise of past suicide bombers;

(b.12) Making payments to families of past suicide-bombers, when and where such payments are not crucial for acts or activities of terror;

(b.13) Issuing posters in praise of past suicide-bombers;

(b.14) Being involved in political, social or religious leadership of an organization that has a terrorist arm without having any personal involvement in decisionmaking processes directly related to acts or activities of terror.

(c) Presumption of Direct Involvement in Terror

(c.1) The Presumption

Persons who were directly involved in an act or an activity of terror during a particular 
period are presumed to be directly involved in terror for an additional half year (or some other period, to be determined on professional intelligence grounds).

(c.2) Validity of Presumption

A military act against persons who are considered to be directly involved in terror only on grounds of the presumption of direct involvement in terror, unless undertaken solely for the purpose of arrest and trial, is right only after a thorough search for evidence to the contrary of the presumption.

(c.3) Significance of Presumption

A military act against persons who are considered to be directly involved in terror only on grounds of the presumption of direct involvement in terror, is right only if it does not involve a risk of collateral damage, i.e. any injury to persons who are not directly involved in terror.

(d) Priorities on Grounds of Duties

Military acts and activities carried out in discharging the duty of the state to defend its citizens against terror acts or activities while at the same time protecting human dignity, should be carried out according to the following priorities which reflect the order of duties the state has toward certain groups:

(d.1) Minimum injury to the lives of citizens of the state who are not combatants during combat;

(d.2) Minimum injury to the lives of other persons (outside the state) who are not involved in terror, when they are under the effective control of the state;

(d.3) Minimum injury to the lives of the combatants of the state in the course of their combat operations;

(d.4) Minimum injury to the lives of other persons (outside the state) who are not involved in terror, when they are not under the effective control of the state;

(d.5) Minimum injury to the lives of other persons (outside the state) who are indirectly involved in terror acts or activities;

(d.6) Injury as required to the liberties or lives of other persons (outside the state) who are directly involved in terror acts or activities.

Proviso: All this applies when the presence of persons directly involved in terror acts or activities within the human environment of other persons not involved in terror, outside the state, has not been created by the state and is of direct responsibility of a foreign power. ${ }^{4}$

\section{Principle B.3}

\section{The Principle of Military Proportionality}

Military acts and activities, carried out in discharging the duty of the state to defend its citizens against terror acts or activities while at the same time protecting human dignity, should take into account, to the greatest possible extent, the following parameters:

On the one hand, components of military benefit:

(f.1) The extent of the danger posed by acts or activities of terror under consideration;

\footnotetext{
${ }^{4}$ The present proviso implies that the state should not force persons who are not directly involved in terror to participate in its military acts or activities in a way that jeopardizes them, e.g., as human shields of combatants. However, requesting the support of such persons which does not jeopardize them at all is morally permissible, e.g., when they are in a position to convince a relative to surrender rather than be killed.
} 
(f.2) The extent of a person's involvement in acts or activities of terror, in accordance with the Principle of Distinction (B.2);

(f.3) The extent to which the danger posed by the act or activity of a person directly involved in terror is immediate;

(f.4) The extent to which the person directly involved in an act or activity of terror has an influence on its performance or continuation;

(f.5) The extent to which the influence of a person directly involved in an act or activity of terror on its performance or continuation is exclusive;

(f.6) The extent to which it is difficult to intercept the person directly involved in an act or activity of terror, because the window of opportunities of whereabouts knowledge is usually not widely open.

On the other hand, collateral damage:

(g.1) The extent of the danger posed by the military act or activity to persons who are not involved in terror at all or not directly involved in terror.

The combination of military benefit considerations and collateral damage considerations will depend on the circumstances:

(h.1) Circumstances of certain military benefit

A high value of one or more of the military benefit parameters (f.1)-(f.6) creates a military necessity for an immediate act, even if the value of the collateral damage parameter is similarly high.

(h.2) Circumstances of probable military benefit

When the value of a military benefit parameter is not high, then the lower is its probability, the more significant is the collateral damage parameter.

(h.3) Circumstances of postponement

When the values of all the military benefit parameters are low, while the value of the collateral damage parameter is not nil, military necessity of an immediate act is not created and a postponement is required to a date of appropriate circumstances.

(h.4) Circumstances of development

Military acts or activities when the collateral damage parameter is of a high value should be followed by attempts to develop new types of weaponry or methods of warfare in order to lower the level of that parameter in the future. ${ }^{5}$

Principle B.4

\section{The Principle of Low Probabilities}

(p.1) Attitude toward Human Life

Low probabilities are not negligible when the events under consideration involve danger to human life.

(p.2) Uncertain Intelligence

Under conditions of uncertain intelligence, the data regarding the severity of the threat under consideration (which is the 'cost' of the error expected if the threat is ignored) will

\footnotetext{
${ }^{5}$ Most of our discussion has been related to concern for human life. Similar considerations do, however, apply to instances in which concern is due to related aspects of human well being.
} 
determine the threshold probability, above which the threat is to be considered as if it were a certain one. An appropriate authority will determine the probability threshold.

(p.3) Maximin Scenario

Under conditions of low probability intelligence or where probabilities cannot be determined regarding a threat or danger, considerations will be made in accordance with the Maximin Principle. ${ }^{6}$ One course of action is preferable to another if the worst possible outcome of the former is less bad than the worst possible outcome of the latter. The value of an outcome is determined according to the priorities of the state on grounds of its duties (B.2(d)).

\section{Principle B.5}

\section{The Principle of Time Span Considerations}

\section{(q.1) Time Span Significance}

In planning any military act or activity, it is required to take into account its consequences with respect to given short-range dangers, soundly assessed medium-range dangers, as well as long-range dangers to the extent they lend themselves to considered professional assessment.

The basic military goal is to prevent the dangers in all time ranges. If it is impossible to prevent all the dangers, the alternative goal would be to minimize the dangers in each time range.

(q.2) Time Span Priorities

Considerations of the military necessity to defend human life in the short range overrule considerations of the duties to defend human life in the medium- and long-ranges, when the latter duties are not of military necessity.

\section{Principle B.6}

\section{The Principle of Professional Understanding}

Every military act and activity of fighting terror should be professionally performed. Accordingly, every such military act and activity should involve an understanding of its nature.

\section{Principles of Fighting Terror, Part III: Military Consciousness-Directed Struggle}

We have already pointed out that since terror involves attempts to kill people in order to terrorize a population, fighting terror involves two battlefronts; one is directly related to the attempts of terrorists to kill people, while the other is directly related to their attempts to terrorize the population in order to achieve some goals of a political or ideological nature. Part II of the proposed Principles of Fighting Terror dealt with the former battlefront. We turn now to the second battlefront.

State activities in the battlefield of public attitudes should be divided into different domains. The first domain is that of the internal public arena. Here the goals are to see to it

\footnotetext{
${ }^{6}$ For a presentation of the principle and a most illustrious application of it, see Rawls (1971). 
that the public not only is not terrorized, but also that it supports the fight against it by the military and other defense agencies of the state. The second domain is that of the 'international community' public arena. Here one goal is to convince the public in various states that the fight against terror is being performed effectively and morally. The third domain is that of the public arena of the home population of the terrorists. Here one goal is to convince the public, first, that terror acts and activities are not going to lead to any political or ideological achievements. A second goal is to convince the public that the fight against terror is a fight against acts or activities of terror as planned and carried out by terrorists, individuals or organizations, and not against the whole surrounding population, be it in sympathy with the strategy of terror or not.

Within the framework of a democratic state only some of those goals may be served by the military. The following principles have to do with the last goal of the last domain.

\section{Principle C.1}

\section{The Principle of Permanent Notice}

When military acts or activities against terror are conducted in a certain area and there is a danger of injury to persons not directly involved in terror, then prior notice acts should be permanently carried out in that area. Such acts should provide an effective warning to those persons of the possibility that they may be injured in a military act to if they and persons directly involved in terror remain in the same vicinity.

\section{Principle C.2}

\section{The Principle of Compensation}

When military acts or activities against terror are conducted in a certain area and there is a possibility of harm being done to property of persons in that area who are not involved in terror, a clarification activity should be conducted in order to explain to those individuals the operational, anti-terror nature of the act or activity. There should also be clarification of the efforts to minimize property damage during the course of military act or activity and the willingness to cooperate with them in an effort to minimize damages.

\section{Principle C.3}

\section{The Principle of Operational Deterrence}

\section{(s.1) Goal and evaluation}

Operational deterrence is meant to prevent acts or activities of terror by means of a practical warning that manifests expected results of military acts and activities against terror.

As such, operational deterrence is a component in the consciousness-directed struggle within the framework of the fight against terror.

The degree of success of operational deterrence is measured with regard to accumulative effects rather than local immediate ones.

(s.2) Clarified Aspect

Operational deterrence is an additional aspect of a military preventive act or activity against an ongoing attempt to carry out an act or activity of terror. 
The deterrence aspect of a military preventive act or activity should always be clarified, post factum, in addition to the ordinary public presentation of the preventive act or activity. (s.3) Collateral Damage

During performance of a military act or activity, the goals of which are both to prevent an ongoing terror act or activity and to deter persons from future terror acts and activities, any injury to persons who are not directly involved in terror, including their well being, is justified only on grounds of the military necessity of the preventive act or activity and not on grounds of the deterrence aspect.

\section{References}

Corlett, J. A. (2003). Terrorism, A philosophical analysis. Dordrecht: Kluwer.

Rawls, J. (1971). A theory of justice. Cambridge, Massachusetts: Harvard University Press.

Schmid, A. P., Jongman, A. J. et al. (1988). Political terrorism: A new Guide, to actors, authors, concepts, data bases, theories, and literature. New Brunswick, New Jersey: Transaction Books. 